\title{
Influerce of the dietary crude' protein level during gestation on long term performance of sows and piglets kept in intensive conditions
}

\author{
O. LAVOREL, J. FEKETE, J.-P. BOUARD et M. LEUILLET \\ Institut Technique des Céréales ef des Fourrages, \\ 8, avenue du Président-Wilson, F 75116 Paris
}

This trial was made between 1976 and 1979 at the Experimental Pig Farm of «Pouline» in Vendome (S.E.A.P.-I.T.C.F.), in order to compare two crude protein levels during gestation (12 and 14.5 p. 100). The feed restriction level during gestation was $2.3 \mathrm{~kg}$ per day and the feed supplies during lactation were the same for both diets : $4.2 \mathrm{~kg}$ of feed including $14.5 \mathrm{p} .100$ crude protein.

The experiment was made with 219 Large White sows corresponding to 309 and 305 litters, respectively distributed over more than 5 successive reproductive cycles.

Weight variation of the sows : the weight of sows at weaning did not exceed $170 \mathrm{~kg}$, which seems to be due to a too severe energy restriction. On the whole, the 14.5 p. 100 diet led to an improvement of the net gain during gestation $(+5 \mathrm{~kg})$, particularly noticeable during the first two cycles. Weight losses during lactation were high (more than $25 \mathrm{~kg}$ ) and slighty higher with the 14.5 p. 100 diet than with the 12 p. 100 diet.

The litter size at birth and the mean weight of piglets at birth were not affected by the sow diet during gestation. Total mortality of piglets during suckling was not affected by the crude protein level during gestation. However, the mortality of piglets occurred sooner with the 12 p. 100 diet than with the 14.5 p. 100 diet during gestation. Variation in the daily mean gain of the litter from birth to weaning seemed to indicate an effect of the crude protein level during gestation from the third cycle on in favour of the 14.5 p. 100 diet. It was not possible to point out any significant difference in sow cullings (number and cause) between both diets.

Comparison between two crude protein levels during gestation showed relatively small differences in sow weight and piglet performance. Moreover, all the experimental results suggest a too severe energy restriction as well as an insufficient crude protein supply during gestation.

\section{Energy value of two types of cassava and comparative utilization in growing pig and piglet diets : results of a joint study by I.N.R.A.-I.T.C.F.-I.T.P.}

\author{
J.-M. PEREZ *, J. CASTAING **, F. GROSJEAN ***, J. CHAUVEL $* * * *$, \\ D. BOURDON * et M. LEUILLET *** \\ * I.N.R.A., Station de Recherches sur l'Elevage des Porcs, \\ Centre de Rennes-Saint-Gilles, $F 35590$ L'Hermitage \\ ** A.G.P.M., I, place de Lestapis, F 64000 Pau \\ *** I.T.C.F., 8, avenue Président-Wilson, F 75116 Paris Cedex \\ *:**** I.T.P., 149, rue de Bercy, F 75595 Paris Cedex 12
}

Four coordinated trials were made to assess the feeding value of 2 types of cassava of different quality (cassava $1: 65$ p. 100 starch, 3.3 p. 100 crude fibre, 4.5 p. 100 ash ; cassava $2: 74$ p. 100 starch, 1.5 p. 100 crude fibre, 2.1 p. 100 ash)) : 